\title{
1. Public utilities: essential services, critical infrastructure
}

During the writing of the first edition of this series on public utilities it was apparent that a transformation was taking place in the way public utilities were managed, regulated, and governed. That managerial transformation had been largely accomplished by the middle of the second decade of the new century. Traditional bureaucratic administration had been or was being replaced by market-driven managerial and entrepreneurial leadership. The historical method of government regulation of utilities as natural monopolies best kept under tight government control was still extant, although it was being replaced by deregulation and privatization, just as it had happened in many other industries. By the late 1990s many publicly owned utilities had to either give way to investorowned governance or find and implement the economic efficiencies that were expected to accrue from free market competition. However, not all of the changes to the regulatory system were as successful as had been hoped. The collapse of a number of deregulated and privatized utilities, a growing number of brownout and blackouts in the electricity sector, and natural gas and water shortages that followed were attributed to the difficulties associated with utility restructuring.

For public utilities in general, many, but not all, of the problems they faced in the last several decades of the twentieth century have been solved. However, new challenges to maintaining sustainability have arisen to replace those that have been resolved. For example, shortages in energy supplies have been replaced by relatively secure supply of oil and natural gas resources. Regulation of the electric and natural gas utility distribution segments of the industry appear to be little changed, but with federal regulators concerned with the need to ensure the security of the nation's electric energy grid and extensive gas and fuel pipeline system. Water and wastewater utilities, nearly exclusively publicly owned enterprises, remain under the often heavy-handed oversight of federal, state and local governments. Like all the sector, water utilities are faced with the need to acquire the funds necessary for repair and replace aging infrastructure while encouraging consumers to use less of what is becoming an increasingly scarce resource. 
Solid waste utilities are running out of sites for ecologically sound landfills while also having to dispose of larger amounts of waste products.

While some hesitancy in the willingness to apply greater regulatory restrictions on utility operations is apparent, the regulatory movement has not disappeared, nor has it eased. Rather, the regulatory focus appears to be more focused on rules and regulations to enhance the sustainability of the public utility system than on rate equability. Regardless of the intent, regulatory changes require investments. The external challenges to the industry brought on by population growth and changing climate conditions have resulted in water shortages and stresses on wastewater and solid waste treatment and disposal facilities. Regulatory developments in these sectors are also leaning toward maintaining and monitoring compliance with public health standards in the face of the climate and environmental stresses that now affect the sustainability of the sector. The telecommunications and cable television sectors, while not discussed in this text, remain overwhelmingly competitive private-sector businesses that remain under federal oversight.

\section{THE PUBLIC UTILITIES CONCEPT}

The term public utilities refers to the collection of specific services provided by public and private organizations and institutions that make up the public services industry. At the broadest level, the services provided have been long been denominated according to the essential services they perform (Glaeser 1957): (1) public transportation, (2) communication services, (3) energy for light, heat and refrigeration services, (4) water, wastewater, drainage, flood protection, and irrigation, and (5) resource conservation through solid and hazardous waste collection and disposal. The products or services provided by the public utility industry include electrical energy, natural gas, water, sanitation, waste disposal and recycling, communications, public rail and bus transportation, and certain types of storage facilities, including public warehouses, and grain elevators, among others. In brief, these are the organizations and institutions that build and maintain the nation's critical infrastructure while providing the essential services necessary for modern civilization. A more detailed definition of public utilities published in the Encyclopedia of Law and Economics in 1999 (online) is included in Box 1.1.

Regardless of their form of ownership, to be regarded as a public utility the entities providing the service utilities are organizations that are affected with a public interest, as called for by Justice Waite in 1877 (Farris and Sampson 1973). Public utilities provide essential services needed by every individual and every other institution in a society. The organizations 


\section{BOX 1.1 WHAT ARE "PUBLIC UTILITIES"?}

"The term 'public utility' encompasses a wide variety of industries including, among others, airlines, telecommunications, oil, natural gas, electricity, trucking, cable television [water and wastewater, solid waste collection and disposal, and public transit]. . . . These industries share a common 'network' structure, in that they have an extensive distribution system of lines, pipes, or routes requiring the use of public rights of way, often with strong physical linkages between component parts. In some cases, such as airlines, government owns a part of the infrastructure. Public utilities typically have substantial sunk costs because of [their extensive infrastructure.]

"Historically, utilities, where privately owned, have been rate-of-return regulated. Utilities are government-owned in some jurisdictions. In almost all cases, utilities have been granted legally enforced monopolies over their service territories.

"Utilities typically create a good or service at one location, and then distribute it over a 'network' where it is delivered to numerous customers for end use. The use of a network structure creates special issues for utilities. The network often exhibits economies of scale and involves substantial sunk costs, so the issue of natural monopoly has played an important role in utility literature. The network may require the use of public streets or other rights of way, so government involvement is of particular concern. Since several firms often utilize the network, there are 'network externalities' or congestion if its use is not properly priced. The activities of utilities can be broken down into three components: production, transmission, and distribution. While the production component has, in the U.S., been almost exclusively privately owned, the transmission and distribution stages have been either private or government-owned."

Source: Geddes (2000).

operating within the various sectors of this industry have the responsibility for seeing that their services are available when and where the public desires them. Collectively, the set of services are referred to as the social capital of a society. Without them, there can be no cities, no nations. More than seventy years ago, Yale economist Irston Barnes suggested the following definition for public utilities:

Those industries are public utilities which are required to render service as reasonable and nondiscriminatory prices to all who apply for it. The measure of regulation thought necessary to insure universal service at reasonable prices will differ widely from one industry to another, but it characteristically begins with prescribing standards of service and price. (Barnes 1942: 1)

For all editions of this book, then, the term public utilities refers to the large group of public service organizations that exist to locate, produce or 
collect, transmit, distribute and/or process and store, a variety of products and services that are vital to modern life. These products and services are ubiquitous. They include the electric energy that lights our workspaces and powers computers, appliances, and motors in offices, stores, factories, and homes. These services also include the natural gas we use to heat our residences, cook our meals, and supply raw material for industrial processes. And, they include the water we drink and the treatment and disposal of our wastewater and household and commercial waste, including the organizations that collect, process, and store our solid and liquid waste, including toxic waste. Also included in this discussion are the many organizations that provide some aspect of public transportation and/or storage are also classified public utilities. It was government regulation of this class of activity - transportation of the public waterways and railroads - that were among the first public utility industries to be brought under government regulation.

\section{Why and How Utilities are "Different"}

Two key factors which distinguish the majority of the utility industry from other economic endeavors are: (1) elements of the utility industry operate under socially-sanctioned conditions of monopoly competition, and (2) one or more element of the organizations' operations or supply chain are regulated by one or more levels of government. U.S. laws require that regulated businesses be managed in ways different in many respects from that of the nonregulated businesses. For example, management decisions in regulated businesses are often subject to public oversight at public utility commission hearings. Public policy and public opinion expect different conduct in many managerial matters, including the setting of prices, the mandate to meet all service-area demand, and restrictions on allowed operating profits, among others.

Because public utilities provide essential public services that are considered to be endowed with a public interest, utilities management requires both public and private sector management knowledge. Market economies must often balance conflicting social and private interests. This is paramount in the utility industry, where there exists a variety of conditions under which economic activities take place. At one end of the range of conditions are the privately owned, nonregulated businesses that range in size from General Electric and General Motors to the independent corner grocery store. At the opposite end of this continuum are the governmentowned organizations such as the U.S. Post Office, TVA, and Bonneville Power; extreme examples at this pole include the nationalized industries that were often found in many Third World countries, the Soviet Bloc 
of nations, and socialist economies such as were found in Great Britain, Sweden, New Zealand, and others. Municipally owned and operated utilities are near to this tradition of public ownership.

Somewhere between the opposite poles of this economic continuum are free-enterprise businesses such as banks, investment brokers, and insurance companies that are subject to varying degrees of special economic regulation. Also in this group are the privately owned public utilities; these have been on the receiving end of the most complete government regulation of any industry in the group. These regulated industries are a diverse group of public service organizations ranging in size and scope from multinational, vertically integrated energy corporations to local water and power cooperatives. These utilities have been subject to government regulation at either the federal, state, or local, or all three levels at once.

Most energy utilities and waste collection operations are privately owned businesses - commonly referred to as investor-owned utilities (IOUs). On the other hand, local governments own most of the nation's water, wastewater, and solid waste disposal site utilities. These governments may operate the utility themselves, or they may contract with private operators for the day-to-day operations; in either case, the government utility may also contract with private firms to perform their billing and customer service functions, among others.

Public utilities differ from other business organizations in many other ways. Six of these differences are: (1) utilities are legally required to serve all customers in their market area without discrimination; (2) they are generally neither exclusively profit or nonprofit; a mix of both types of organizations exist, often side-by-side; (3) utility income often includes a mix of earnings from rates charged customers, stocks and bonds, and/or taxes; (4) utilities are economic organizations because there is a cost to produce and a price for supply of the products, regardless of what form of ownership or governance that characterizes the organization involved in the industry; (5) utilities often practice legally sanctioned price discrimination; and (6) prices for the utility's product or service often do not reflect supply and demand market forces.

These differences from other industries occur for a number of reasons. First, unlike other types of businesses, utilities are legally required to serve all customers in their market area without discrimination; they are limited in this requirement only by their capacity, and may be required to construct additional capacity if demand warrants.

\section{A Mix of Governance Models}

Second, they are generally neither exclusively profit or nonprofit; a mix of both types of organizations exist, often side-by-side, functioning in 
the same chain of production or collection and distribution or processing. Third, utilities' income often includes a mix of earnings from rates charged customers, stocks and bonds, and/or taxes. Taxes may be applied in a variety of different ways. For example, the allocations to the utility may come from a general fund, as in the case of large, publicly owned hydroelectric projects, or in the form of special assessments (one-time, single purpose tax levies) placed upon property owners who benefit from the utility, as in the case of sewer installation charges to property owners who may be served by the line.

Fourth, utilities are economic rather than social organizations. This is because there is an economic cost to produce and a price for supply of the products, regardless of what form of ownership or governance that characterizes the organization involved in the industry. Fifth, utilities often practice legally sanctioned price discrimination. Utilities are supposed to provide a common benefit to each class of users, but users do not always enjoy equal benefit from the products of the utility. Moreover, homeowners are often charged a higher rate for the service than are industrial users, for example. This is often seen as an unfair subsidy from some ratepayers and/or general taxpayers to organizations such as businesses. This discrepancy has long been a source of bitter debate and controversy. Despite this legally sanctioned price discrimination, prices charged by utilities to all their customers must be seen as "reasonable" by regulators and the general public.

Sixth, prices for the product or service often do not reflect supply and demand market forces. Rather, prices for many public utilities are set as more or less arbitrary mandates by governmental regulatory bodies after a series of public hearings and supplier justification. In the case of publicly owned utilities, prices are often kept artificially low for political purposes and do not take into consideration the true cost of the service. True costs would give greater consideration to depreciation and the cost to maintain emergency reserves which are mandated by regulatory agencies. With investor-owned utilities, commissions weigh all the cost data provided by the firm to justify their rates. In addition, regulated utilities are allowed to add a legislatively established minimum rate of return to the accepted cost of their operations.

\section{Why Utilities are Monopolies}

A fundamental economic principle that is most often pointed to as the key factor that differentiates utilities from all other forms of economic organizations is that of a natural monopoly. In economics, two types of monopolies can exist: natural and artificial. Natural monopolies occur 
when a single firm is able to supply a market at a cost and price far lower than would be possible if several firms served the market. This advantage is typically brought about through economies of scale, although other factors including patents and site limitations, also contribute. Site limitations refer to the limited number of locations suitable for hydroelectric dams, reservoirs, gas and wind turbines, suitable places for solid waste disposal, or where natural gas can be found and/or stored. They also refer to the "Not in My Backyard" (NIMBY) phenomenon.

Artificial monopolies, on the other hand, occur because of legal barriers to entry of competitors. The most common example seen today is the exclusive franchise granted to one or a few utilities by municipalities. In Seattle, Washington, for example, solid waste collection franchises for operating in distinct areas of the city were awarded to privately owned firms that submit the lowest bid for the service. Transfer stations and disposal sites, on the other hand, may be owned and operated by the county, or jointly owned by cities and the county. The franchise to construct and operate a cable television system in a community is also usually awarded to a single firm.

\section{The Natural Monopoly Concept}

The concept of utilities being a natural monopoly came into general use during the Progressive Era reform movement, when the federal government began its first experiments with ways to control the perceived excesses of the very large and growing businesses, cartels, trusts, and early utilities. The American economist Richard T. Ely is credited with being the first to use the term. In his Monopolies and Trusts (Ely 1900), Ely defined natural monopolies as businesses that functioned in situations where monopolies not only occurred naturally, inevitably, and were also socially desirableprovided that they were controlled by public regulation or public ownership. In summary, then:

The concept of natural monopoly emerged in the U.S. and by 1910 had acquired a place within American economics. It has sprung out of discussions on how the law should respond to large-scale business, public utilities, and monopolies and against the backdrop of an antitrust legislation and local governmental attempts to foster competition among franchised utilities.

Economists, politicians, and reformer groups were willing to accept the idea that public utilities might serve the public better if they were exempt from anti-trust laws only on the condition that they retained the right to keep the monopoly organizations - public and private - on a tight regulatory leash. The tightest form of regulation has always been, of course, 
public ownership. Although popular in a few states for a short time, this idea never gained full sway in American politics. Business lobbies, existing cartels, and the rapidly growing industrial and commercial sector found the idea of public ownership an anathema. However, there was enough support in many parts of the country - particularly the middle and far western states - for public ownership of utilities to gain a solid foundation.

The public ownership movement received a further incentive when many investor-owned utility trusts collapsed with the 1929 Depression. The result of that collapse was passage of the most far-reaching regulatory legislation to that time, the Public Utility Holding Company Act of 1935 (PUHCA). This important law and its impact on the industry cannot be overestimated. It was enacted during the Great Depression after the pyramided financial structure of large holding companies collapsed with the Stock Market Crash in October 1929. The ramifications of this legislation will be discussed in some detail in a later chapter.

\section{BIRTH OF AN INDUSTRY BASED ON SERVICE}

The public utility industry was born and grew to a boisterous young adulthood in the last two decades of the nineteenth century and the first ten years of the twentieth century. Fortuitously, the industry was developing at the same time that a professional civil bureaucracy was being trained to take on the responsibility of administering the delivery of goods and services for the public good. At the same time, public opinion-fueled by reform organizations like the nearly 22,000 local organizations of the Grange movement-had shifted in favor of government regulation of many types of private businesses.

The underlying idea of a business important enough to be regulated by government first appeared in U.S. Supreme Court Chief Justice Waite's majority opinion in the 1877 case of Munn v. Illinois, 94 U.S. 113 (Glaeser 1957). The state of Illinois had passed a law declaring elevators public utilities and subject to price regulation by the state. The law established maximum fees that could be charged by grain elevators. The Munn and Scott elevator refused to go along with the fixed price maximums, saying that the state had no jurisdiction and charged higher rates. A lower court ruled in favor of the state; Munn and Scott were found guilty and fined. Munn and Scott appealed the decision to the U.S. Supreme Court on the basis that such regulation had never been in place in the past and that lowering their rates would deprive them of their private property, making the decision unconstitutional. The Court upheld the lower court decision. In his opinion, Chief Justice Waite described grain storage as a business 
"affected with a public interest," and therefore needful of regulation. It would not be long before other industries would be cloaked in the same "public interest" mantle.

The seeds of the regulation idea were planted many years earlier than the 1877 landmark Supreme Court case, however. One of the earliest United States applications of a ruling in the public interest can be found in provisions in the Ordinance of 1787, which mandated free navigation on the Nation's waterways (Hull and Hull 1967). But far earlier than this, municipal provision and distribution of water for human consumption was a feature of the theocratic city states that helped to create civilization in the lands of Mesopotamia, in Egypt, and the Indus Valley on the Indian sub-continent. A system of aqueducts for long-distance transmission and hand-crafted lead pipes for municipal distribution water was also one of the major distinguishing characteristics of the Roman Empire.

In North America, the first water supply system was built in Boston in 1652. It consisted of a simple reservoir where water gathered from five springs was stored for public use. A more complex system consisting of a wooden pump, reservoir, and pipes made from hollowed-out logs was established at Bethlehem, Pennsylvania, in 1754. Providence, Rhode Island, developed its system in 1772. These three were the first recorded water supply systems in North America.

\section{Post-Civil War Changes}

Society, along with owners of industry and commercial businesses needs healthy workers, a safe, clean source of energy and lighting, a reliable transportation system, and a means of communicating rapidly. Growth in the scale and scope of the utilities that would meet these needs resulted from the revolution in management thinking and decision-making that took place after the Civil War (Chandler and Tedlow 1985). This change was brought about first because of the inability of older, informal management practices to cope with the increased size and scope of public and private utility businesses. An extensive consolidation of coal, oil and electric energy businesses that began with a wave of mergers unprecedented in scope anywhere in the world to that time took place in the twenty years from 1890 to 1910 . At the same time, a shift was taking place in the way that managers made decisions. For example, pricing and production decisions about energy products and services that had previously only reacted to what Adam Smith called the "invisible hand" of the market, would eventually come to be made internally in order to influence, rather than react to, market demand.

The management shift that was taking place in the public service sector 
at this time began in Europe with reforms proposed by Max Weber (Christensen and Lægreid 2002). Weber called for the traditional spoils system approach to government employment to be replaced by a cadre of professional civil servants, selected by merit, organized into bureaucracies, and motivated by an ethos of public service. The spoils system lasted longer in the United States but was finally subsumed by a system of professional public servants, organized according to skill categories spelled out in a rule-based civil service code. These changes in public administration were almost fully in place by the onset of the First World War.

\section{The Utility Reform Movement}

The utility reform movement underway in the last two decades of the twentieth century was founded on four main components: (1) limits to civil service autonomy to make government more responsive to political influence; (2) introduction of performance-based private sector management principles and practices to improve operational efficiency, effectiveness, and accountability; (3) greater transparency in operations, with increased participation by individuals, consumer groups, and local communities in the design and delivery of all public services; and (4) widespread deregulation of investor-owned utilities. Collectively, these four forces are the foundation stones of what has been referred to as the New Public Management (NPM).

Many European governments, including Sweden, Italy, France, and Germany, among others, have adopted elements of NPM. Other Western nations, such as New Zealand, Canada, Brazil, and Australia, have also implemented NPM policies. The nations that have adopted NPM have done so with a number of similar purposes; these include the reduction of public spending and reduced public employment, reduction of deficits and debt service, meeting a perceived need to modernize and improve the management of government services, and bringing about a turnaround in the global trend of citizens' distrust in government.

Organizations such as the World Bank and the EU encouraged their lesser developed client states to adopt NPM policies designed to shift public sector operations from their traditional hierarchical, rule-based, process-oriented, bureaucratic structures toward a flatter, performancebased, organizational model in which public managers are willing to take risks, including contracting with private industry for the provision of public utility services. In addition, the public service deliverers-public and private - had to expand and upgrade their earlier infrastructure, while at the same time continuing to provide quality services. The global payoff sought for the reforms were development of ethical, motivated, public 
servants trained in the skills of risk-taking, public-private sector partnerships, management of scarce resources, strategic planning, and continuous learning required by a global economy. The ultimate promise was a revitalized, modern, public service and utility governance system that is responsible and responsive to the needs of all stakeholders.

\section{Twentieth Century Reforms}

A series of paradigm shifts in the way public utility services function in the United states and other Western democracies occurred over the last hundred years. Calls for change in economic systems first appeared near the start of the last century as laissez faire economic principles were replaced by federal and state legislative controls. The next big change occurred during the Great Depression of the 1930s. The latest call for replacement for the bureaucratic model of public administration developed by Max Weber and added to by Woodrow Wilson first appeared in New Zealand, was then adopted in the United Kingdom in the 1970s under the leadership of Prime Minister Margaret Thatcher (Barzelay 2001). Known as the New Public Management (NPM), it was made popular shortly afterward in the United States by President Ronald Reagan. This shift away from the bureaucratic management model began in the twentieth and early twentyfirst century as a search for ways to implement transformational changes in the traditional bureaucratic model of public administration.

Over the last two decades of the twentieth century, the authoritative administrative system with detailed federal and state government regulation was replaced by a market-oriented management system characterized by privatization and increased user fees for public services, the appearance of more and more public and private sector partnerships, management's adoption of long-term strategic planning and programs, evaluation and accountability, and a flattening of the administrative hierarchy. The interest of public administration reformers in the NPM management paradigm, while not dead, has stagnated at best.

\section{Forces that Shaped the Modern Utilities Sector}

Three operating environmental forces combined in the last half of the twentieth century and the early decades of the twenty-first century to bring about a deep reaching transformation in the economic structure of most of the industrialized nations of the world. The first was a shift in their demographic makeup and urbanization of their populations. An aging population and concentration of people in cities eventually made possible a truly reachable mass market. At the same time, population 
growth in the developing nations pushed many men and women to migrate to new and developing regions. Private enterprise in the energy, and telecommunication industries rose to meet the challenge. The need to provide basic services such as water, wastewater, energy and waste disposal for the growing populations had to be met by municipal governments and publicly owned utilities. Hence, much of the public utility sector's infrastructure was put into place in the thirty years following the end of the Second World War. Now, much of that infrastructure is either inadequate to meet existing needs or must be repaired or replaced.

\section{A Wedding of Science and Capital}

The second transformational force was the application of science and information technology advancement to management, invention and the consolidation of the major industries in the each of the major economies. Before the period ended, the energy industry shifted from coal to petroleum products to coal gas to natural gas - all under the hands of private investors and entrepreneurs. In the water, wastewater and solid waste sector, publicly owned enterprises were redesigned and developed to do the same. The science of making water safe for consumption made greater growth of cities possible.

Consolidation through mergers acquisitions in the energy and telecommunications sectors evolved from the formation of cartels and trusts monopolistic or oligopolistic competition that characterized the energy sector in the nineteenth and first quarter of the twentieth century. The capital needed was made available through bond sales or long-term loans. In the publicly or municipally owned sectors, the same large amounts of capital were needed; the same financial institutions that served the private firms provided the same services to publicly owned utilities, with security for the bonds assured by the power to tax and repaid through fees for services. Because all these services were deemed to be essential and competition was not considered possible, most became heavily regulated "natural" monopolies. All required huge amounts of capital to develop the infrastructure needed to meet the growing demand for their services; government regulation ensured that capital providers retrieved safe returns on their investments.

The third force was a revolution in the technology of transportation, communication, and human health services. These changes made possible the mass distribution of goods and services for the new mass markets and provided for the health and welfare of the growing population. The revolution in transportation and large capital constructions such as dams, water and wastewater systems was made possible by the skills gained in the 
development of the nation's railroads and by application of steam power to inland and ocean-going navigation. The communications revolution began with the telegraph and was reinforced by growth of the railroad. By the turn of the century, telephones had been invented and were in widespread use. The revolution in telecommunications brought about by development of personal computers, the Internet and cellular telephones continues to foster changes in societies around the globe. Human health has been improved by the provision of clean water and safe collection and processing of wastewater and garbage. The development of new antibiotics and other life-saving pharmaceuticals has contributed to improved health and lengthened the life span of people everywhere.

Population growth and its movement from the farm into cities that were increasingly linked by railroads continued throughout most of the nineteenth century. The population of the United States rose from 31 million in 1860 to 63 million in 1890 and to 106 million in 1920. Most of this growth was caused by a wave of immigration from eastern and southern Europe. These immigrants more often than not settled in the nation's cities and went to work in the new factories and mines. This process started a major shift from the agrarian character of the nation that existed since colonial times toward an industrialized society. In 1860, only 16 percent of Americans lived in towns or cities with a population greater than 5,000. That proportion had risen to 33 percent by 1900 .

As the cities filled up with new immigrants, a number of important social problems came to the fore. Cities were becoming increasingly dark, dank, and crowded with the poor. Crime and sickness were rampant. Neither sanitation nor running water could be found in the slums housing many of the new Americans. To continue to grow and thrive, cities needed to have sources of safe, affordable water, sanitation systems, street and interior lighting, municipal transportation, reliable, affordable energy, and dependable and fast means of near and distant communication. The mechanisms that met these needs at the turn of the century-horses and human muscles, manufactured-gas lighting, and coal and wood-fired steam generators - were not able to keep up with the demands fueled by the new nation's unprecedented urban growth.

\section{FORCES SHAPING THE MODERN INDUSTRY}

During the decade after publication of the first edition of this text, the global water and electric utilities industries have undergone substantial changes in the type and scope of the challenges facing managers and administrators of those organizations. Today there are at least four 
megatrends that impact all utilities, regardless of size, location, or sector, and which function as major barriers to their continued sustainability. The first trend includes the changes occurring in the source and type of product and service supplied. On one hand, the once abundant water supplies are declining rapidly, droughts are longer and occurring more often, wastewater and solid waste disposal methods and sites are becoming more restricted, while on the other, the availability and use of once-scarce domestic supplies of energy supplies have increased dramatically, resulting in deep declines in prices. The second trend involves the supply and delivery changes made necessary by changing climate conditions and for replacement and repair of aging and obsolete infrastructure.

A third is the growing difficulty of coming up with funds needed to pay for the improvements needed to meet the needs of demographic changes to society; federal financial support continues to decline while the ability to impose increases in rates is more problematic. A fourth trend is the operational changes imposed upon all public service organizations because of the security threat imposed by domestic terrorist activity.

For many public utilities, the financial challenges are exacerbated by the significant drop in service income brought about by successful conservation developments. Financial needs are growing faster than income for nearly all utilities. The ability to implement changes in rates or to use a different rate structure for different classes of users is becoming problematic due to court-instituted changes and restrictions.

This new edition of the challenges and opportunities facing public utilities was planned as a way to help bring to public awareness the challenges facing public and private utilities. In the long run, rate payers are responsible for providing utility managers with the wherewithal to overcome these and other challenges. However, the book does not address technical issues; rather it focuses on the administrative legal, political and economic issues that commissioners and administrators of large and small public utilities must deal with every day. It is also intended for the leaders of communities, and for the students of utility operations that will be the managers and commissioners of the future.

Investor-owned utilities and those owned by community groups, municipalities, counties, and regional organizations in the United States and elsewhere in the world continue to go far in surmounting many of the challenges they faced in the first decade of the new century. However, they know their work is not done; the many new challenges they face a decade later may be even more difficult to overcome. Many of these issues appear to be attributable to what many scientists believe to be the warming of the climate. A warmer climate in some regions has resulted in severe drought and overstressed water resources, while in others the changes have resulted 
in more severe rainstorms, hurricanes and cyclones. Arid areas such as the western U.S. and Asia have become more arid while population growth is beginning to over-tax limited water supplies in many of these regions. There is just so much freshwater available and many supplies are already under strain. Parts of the U.S. and elsewhere are undergoing a long-term drought, one for which no early end is in sight. At the opposite end of the scale, other areas are forced to deal with the effects of weather trends that are increasingly severe and damaging to existing infrastructure. Added to the supply problem is that much of the country's water and wastewater infrastructure is one to several hundred years old and buried under metropolitan streets. In the U.S., for example, many of the major mains serving cities were constructed in the nineteenth century. In Europe and Asia, many are even older. Much of that infrastructure is beginning to fail at the same time that supplies are reaching or beyond their sustainability.

\section{SUMMARY}

The term public utility is used to describe a variety of publicly and investorowned organizations that provide certain specific essential services to residential consumers, industrial and commercial customers, and government organizations. U.S. Supreme Court decisions dealing with the services provided by utilities have resulted in those services being 'affected with the public interest,' and therefore deserving of government regulation.

Utilities are supposed to provide a common benefit to each class of users, but users do not always enjoy equal benefit from the products of the utility. Moreover, homeowners are often charged a higher rate for the service than are industrial users, for example. Despite this legally sanctioned price discrimination, prices charged by utilities to all their customers must be seen as "reasonable" by regulators and the general public. In the case of publicly owned utilities, prices are often kept artificially low for political purposes and do not take into consideration the true cost of the service. With investor-owned utilities, commissions weigh all the cost data provided by the firm to justify their rates. Regulated utilities are allowed to add a legislatively established minimum rate of return to the accepted cost of their operations.

A fundamental economic principle that differentiates utilities from all other forms of economic organizations is that of the natural monopoly. Natural monopolies occur when a single firm is able to supply a market at a cost and price far lower than would be possible if several firms served the market. The concept of utilities being a natural monopoly came into general use during the Progressive Era reform movement, when the federal 
government began its first experiments with ways to control the perceived excesses of the very large and growing businesses, cartels, trusts, and early utilities.

\section{ADDITIONAL READING}

Coe, Charles K. (2015), Urban Services: A Basic Guide for Local Governments. New York: Routledge.

Colburn, David R. and George E. Pozzetta (eds) (1983), Reform and Reformers in the Progressive Era. Westport, CT: Greenwood Press.

Glaeser, Martin G. (1957), Public Utilities in American Capitalism. New York: Macmillan.

Lambert, Jeremiah D. (2015), The Power Brokers: The Struggle to Shape and Control the Electric Power Industry. Cambridge, MA: MIT Press.

Morgan, C.S. (2010), Regulation and the Management of Public Utilities. Boston: Gale (Cengage).

Pond, Oscar L. (2012), Municipal Control of Public Utilities; a Study of the Attitude of Our Courts Toward an Increase in the Sphere of Municipal Activity, Lenox, MA: HardPress. 